\title{
Performansi Sistem Pengendali Kecepatan Motor BLDC Menggunakan Logika Fuzzy Logic
}

\author{
( Wayan Widhiada ${ }^{1)^{\star}}$, Made Widiyarta ${ }^{2}$, K.P. Arya Utama ${ }^{3)}$ \\ 1,2,3) Jurusan Teknik Mesin Fakultas Teknik Universitas Udayana \\ Kampus Bukit Jimbaran, Bali 80362 \\ Email:wynwidhiada@unud.ac.id, m widiyarta@unud.ac.id, aryautama93@gmail.com
}

doi: https://doi.org/10.24843/METTEK.2020.v06.i01.p02

\begin{abstract}
Abstrak
Brushless DC motor adalah salah satu jenis motor sinkron yang diberi arus DC yang bersumber dari inverter atau power supply. Motor AC menghasilkan arus AC yang dapat menggerakan motor. Pada dasarnya kecepatan motor dapat di atur menggunakan kontroler yang menghitung seberapa besar keluaran yang harus dihasilkan. Pada umumnya input dari kontroler berupa tuas (naik - turun atau putar) dan tombol untuk input awalnya. Oleh Karena itu dilakukan penelitian untuk mengganti input yang mengatur kecepatan motor BLDC. Kontrol kecepatan motor BLDC berbasis logika fuzzy adalah suatu system kontrol yang mengganti input main stream dari kontroler menjadi sensor beban, dan dimana pembacaanya akan dikontrol oleh logika fuzzy untuk mengatur control kecepatan motor BLDC. Penelitian dilakukan dengan dua cara yaitu simulasi dan eksperimen prototype dengan pemberian beban pada sensor yaitu $10 \mathrm{~kg}, 20 \mathrm{~kg}, 30 \mathrm{~kg}, 40 \mathrm{~kg}$ dan $50 \mathrm{~kg}$ sebagai inputnya. Hasil dari pengujian dan penghitungan yang didapat pada setiap pembebanan menghasilkan kecepatan yang stabil yaitu rata - rata 0.25 detik dengan kecepatan yang hamper setara dengan referensinya. Error pada kecepatan yang dihasilkan antara simulasi dan prototype sangat kecil yaitu kurang dari $1 \%$ pada masing - masing pembebanan.
\end{abstract}

Kata kunci: Kontrol kecepatan BLDC, logika fuzzy

\begin{abstract}
Brushless DC motor is one type of synchronous motor that is given a DC current from the inverter or power supply sourced. It produces an AC current that can drive the motor. Basically the motor speed can be set using a controller to compute the result of output. In general, the input from the controller is like a handle (up - down or twist) and a button for initial input. Therefore the research has changed the input that regulates the speed of the BLDC motor. BLDC motor speed is controlled based on fuzzy logic. Fuzzy logic is a control who help load sensor to replace the mainstream input like handle, and where the reader will be directed by logic to determine the speed of the BLDC motor. The research is carried out in two techniques, called simulation and experiment. The prototype is testing with the load on $10 \mathrm{~kg}, 20 \mathrm{~kg}, 30 \mathrm{~kg}, 40 \mathrm{~kg}$ and $50 \mathrm{~kg}$ as an input. The results of the tests is obtained at each loading resulted in a stable speed which is an average of 0.25 seconds with a speed that is almost the same as the reference. The error signal of the speed is produced between the simulation and prototype is very small, which is less than $1 \%$ in each load.
\end{abstract}

Keywords: BLDC Speed Controller, Fuzzy Logic

Penulis korespondensi,

Email: wynwidhiada@unud.ac.id 


\section{PENDAHULUAN}

Permanen magnet telah digunakan dalam mesin listrik selama lebih dari 100 tahun, tetapi karena banyak pengembangan beberapa tahun kebelakang ini dalam sifat dan ketersediaannya, aplikasi mereka dalam perangkat elektro-mekanis dan elektronik sekarang berkembang pesat.

.Kendaraan listrik memiliki beberapa keunggulan dibandingkan dengan mesin mobil pembakaran internal, termasuk pengurangan polusi udara yang signifikan, pengurangan emisi gas, dan mengurangi ketergantungan energi pada berkurangnya cadangan minyak. Kendaraan listrik akan menggunakan listrik yang tersimpan di baterai untuk menggerakkan motor, dan daya dapat diisi ulang dengan pembangkitan listrik menggunakan energi terbarukan. Dari berbagai motor listrik, motor yang paling cocok untuk kendaraan listrik adalah motor BLDC[1].

Brushless DC electric motor (BLDC motor atau BL motor) juga dikenal sebagai Electrically Commutated Motor (ECMs atau ECM motor) adalah suatu jenis motor sinkron yang diberi arus DC yang bersumber dari inverter atau power supply, dimana menghasilkan arus AC yang dapat menjalankan motor. Artinya medan magnet yang dihasilkan oleh strator dan medan magnet yang dihasilkan oleh rotor berputar di frekuensi yang sama. BLDC motor tidak mengalami slip, tidak seperti yang terjadi pada motor induksi biasa. BLDC motor mungkin bisa disebut sebagai motor stepper, tetapi motor stepper digunakan sebagai motor yang didesain khusus untuk mengoperasikan mode dimana motor dapat berhenti dimana rotor dapat didefinisikan sebagai posisi. Pada BLDC motor, terdapat dua kumparan energy dengan polaritas yang sama dan berlawanan pada saat bersamaan, satu kumparan yang mendorong rotor menjauh dan kumparan yang lain menarik rotor untuk mendekat. Ini dapat meningkatkan kapasitas torsi keseluruhan dari motor dan Hall effect sensor atau rotary encoder yang menentukan kumparan mana yang harus diberi energy untuk mendapatkan putaran [2]. Pada kenyataan sangatlah sulit untuk mengatur kecepatan putaran motor BLDC sampai mencapai kestabilan dalam waktu tertentu.

Berdasarkan permasalahan diatas, kami ingin mengangkat penelitian tentang system control kecepatan putaran BLDC motor dengan menggunakan Arduino Uno sebagai mikrokontroler yang berfungsi sebagai I/O (input dan output) dan Load Sensor yang berfungsi sebagai input untuk mikrokontroler. Program Fuzzy Logic digunakan untuk mengontrol kecepatan putaran motor BLDC dengan variasi beban [3].

Metode yang akan digunakan penulis dalam penelitian ini adalah simulasi dan eksperimental, nantinya penulis akan membuat simulasi yang berbasis MATLAB/Simulink untuk digunakan sebagai pembanding dari data yang telah diambil dari eksperimen tentang system control kecepatan motor BLDC yang menggunakan mikrokontroler. Hasil yang diharapkan oleh penulisnya itu perbandingan antara simulasi dan eksperimen tidak melewati batas error, waktu respon dan waktu steady yang telah ditentukan [4] .

\section{METODE}

\subsection{Gambaran Singkat}

Prinsip kerja dari penelitian ini adalah memindahkan motor BLDC (Brushless DC) dengan menggunakan sensor beban (Load Sensor) sebagai input dan untuk diteruskan ke Arduino. Data yang diperoleh oleh Arduino akan diproses melalui perangkat lunak seperti perangkat lunak yaitu MATLAB. Dalam MATLAB, data yang telah diperoleh melalui Arduino akan diproses kembali menggunakan logika fuzzy untuk menentukan tingkat keanggotaan data yang diperoleh. Setelah data atau hasil yang telah dihasilkan diperoleh, data tersebut akan dipandu oleh motor BLDC untuk bergerak. Kecepatan motor BLDC akan bervariasi sesuai dengan input sensor bebas, karena beban pada sensor meningkat, kecepatan motor akan meningkat dan sebaliknya jika beban berkurang, kecepatan motor juga akan berkurang. 
Penelitian ini dengan menggunakan metode simulasi dan eksperimen. Penelitian ini dimulai dengan membuat serangkaian urutan dengan menggunakan aplikasi MATLAB/Simulink. Setelah simulasi dilakukan MATLAB dan mendapatkan hasilnya, maka penulis membuat serangkaian alat uji kecepatan putar motor BLDC dengan menggunakan program Fuzzy Logic Control [5,6]. Setelah data dari simulasi dan penelitian eksperimental diperoleh, langkah selanjutnya dari penulisan akan membandingkan hasil dari simulasi dan eksperimen. Kemudi perbandingan dapat ditarik dengan kesimpulan meningkatkan kecepatan respons, kecepatan rotasi dan kesalahan hasil yang diperoleh.

\subsection{Pemodelan Motor BLDC}

Pemodelan matematika motor BLDC dibagi menjadi dua bagian adalah sama dengan yang setara listrik dan mekanik. Berikut ini adalah persamaan listrik motor BLDC:

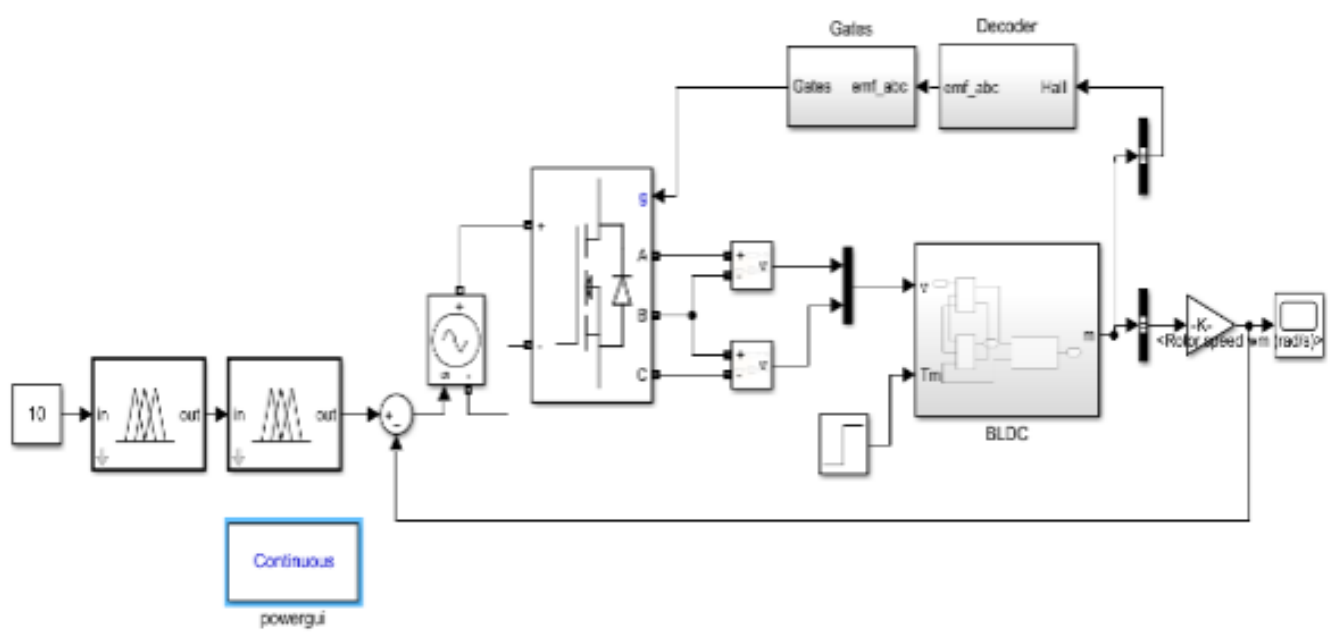

Gambar 1. Pemodelan Simulasi Kontrol BLDC

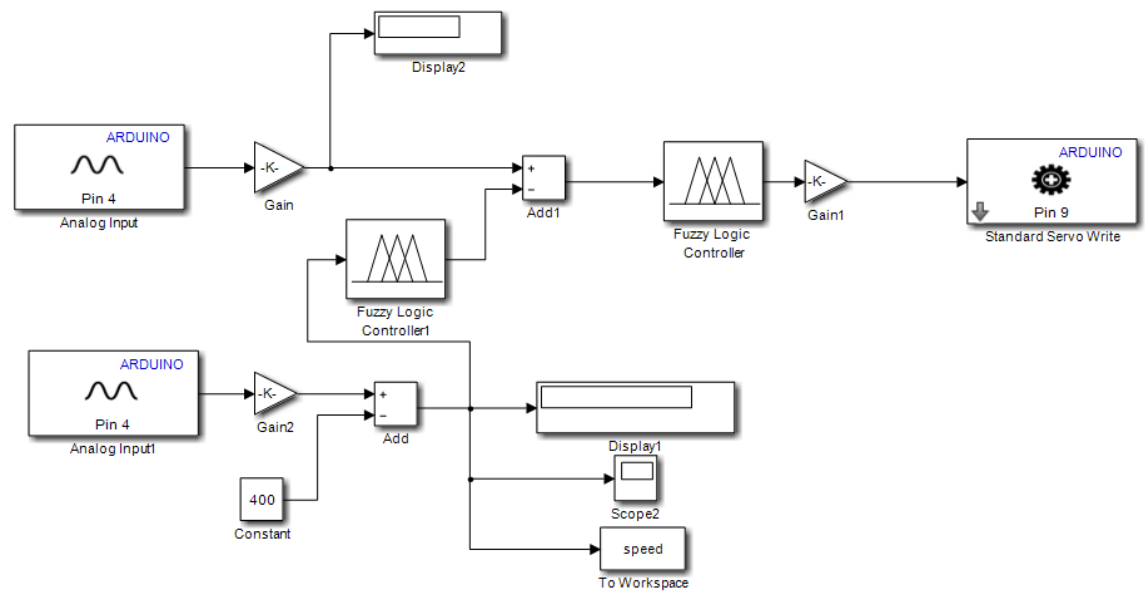

Gambar 2. Program Sisten Kontrol Pengujian Motor BLDC dengan Fuzzy Logic 


\subsection{Program Fuzzy Logic}

Logika fuzzy adalah peningkatan dari logika Boolean atau lebih dikenal sebagai aljabar Boolean yang memiliki beberapa kebenaran konseptual. Ketika logika Boolean menyatakan bahwa dapat dikatakan bahwa ada sesuatu dalam istilah Binerean atau data yang memiliki nilai (0 atau 1, benar atau salah, ya atau tidak, hitam atau putih), dalam logika fuzzy menggantikan beberapa kebenaran Boolean dengan fuzzy tingkat kebenaran. Logika fuzzy umumnya diterapkan pada masalah yang mengandung ketidakpastian (uncentainty), tidak tepat, berisik, dan sebagainya. Logika jembatan ini membahas mesin yang tepat dengan bahasa manusia yang menekankan arti atau signifikansi, berikut adalah contoh penerapan logika fuzzy.

Dalam sistem logika kontrol fuzzy, fase operasional disediakan:

1) Fuzzyfication

2) Penalaran (Mesin Inferensi)

3) Aturan Dasar (Berdasarkan Aturan)

4) Defuzzyfication

Diagram blok fuzzy controllogram ditunjukkan pada gambar berikut:

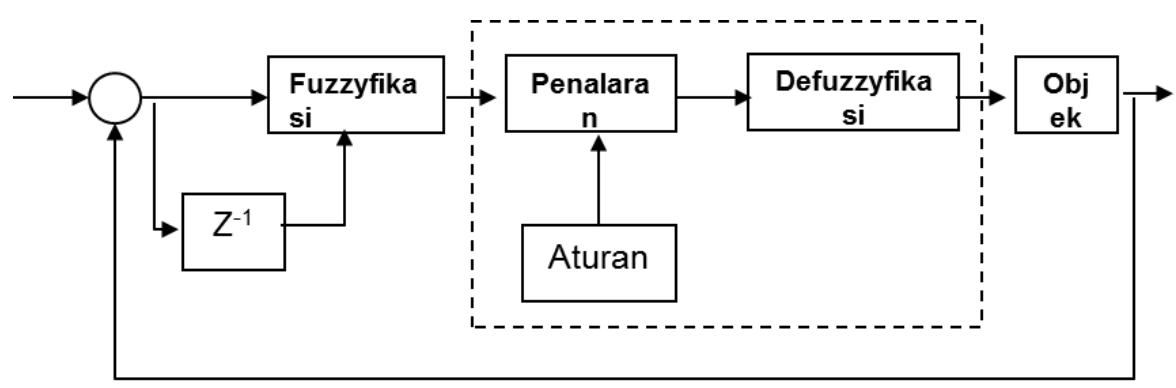

\subsection{Prosedur Pengujian}

Gambar 3. Blok Diagram Fuzzy

Prosedur yang akan dilakukan selama pengujian dari penelitian ini adalah:

1 Penelitian dilakukan dengan mengambil data dari simulasi yang terkandung dalam matlab.

2 Pengumpulan data pertama dengan beban $10 \mathrm{~kg}$.

3 Pengambilan data ke dalam lima data BLDC dengan masing-masing beban yang diberikan adalah $20 \mathrm{~kg}, 30 \mathrm{~kg}, 40 \mathrm{~kg}$ dan $50 \mathrm{~kg}$.

4 Selanjutnya, pengukuran parameter yang diukur dilakukan, yaitu: Sebuah. Kecepatan BLDC

b. Waktu respons pada sepeda motor 


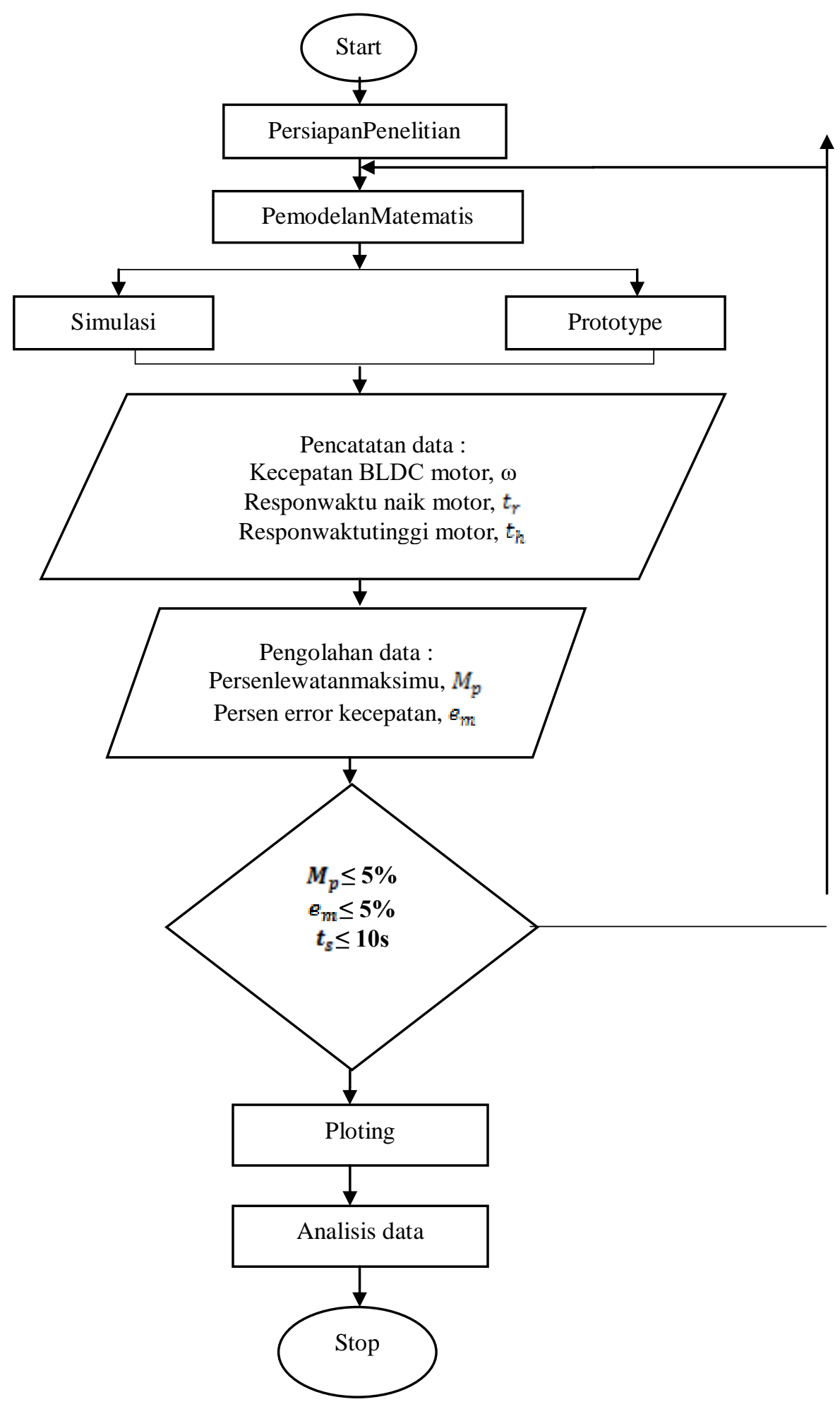

Gambar 4. Diagram Alir Penelitian

\section{HASIL DAN PEMBAHASAN}

Grafik perbandingan kontrol kecepatan motor BLDC antara simulasi dan eksperimen sebagai berikut:

Pada gambar 5 menunjukkan perbandingan hasil simulasi dan eksperimen dari system 
kontrol motor BLDC dengan pembebanan seberat $10 \mathrm{~kg}$. Pada grafik menunjukkan terjadinya overshot yang melebihi $2500 \mathrm{rpm}$ pada saat 0.026 detik pada saat diberikan input dan terjadi sedikit osilasi pada eksperimen hingga osilasi mengecil dan stabil pada kecepatan $2375 \mathrm{rpm}$ saat 0.139 detik. Pembebanan yang tiba - tiba pada sensor menyebabkan lonjakan data pada input menyebabkan kecepatan awal pada eksperimen tidak sama dengan simulasi, menyebabkan terjadinya overshot pada data kecepatan eksperimen.

Pembebanan $20 \mathrm{~kg}$ pada simulasi dan eksperimen yang ditunjukkan gambar 6. Maksimum overshot terjadi pada percobaan uji alat dengan kecepatan $2725 \mathrm{rpm}$ pada 0.027 detik dan simulasi di kecepatan 2587 RPM dengan waktu 0.024 detik. Respon naikkan dari eksperimen mengalami osilasi yang tidak terlalu besar, meskipun mencapai kecepatan stabil pada saat 0.139 detik dengan kecepatan 2489 RPM.

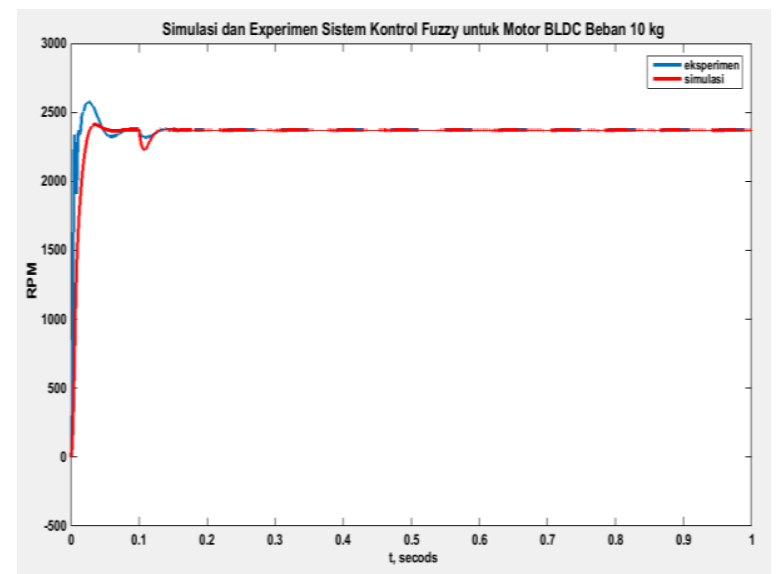

Gambar 5. Simulasi VS Prototype beban $10 \mathrm{~kg}$

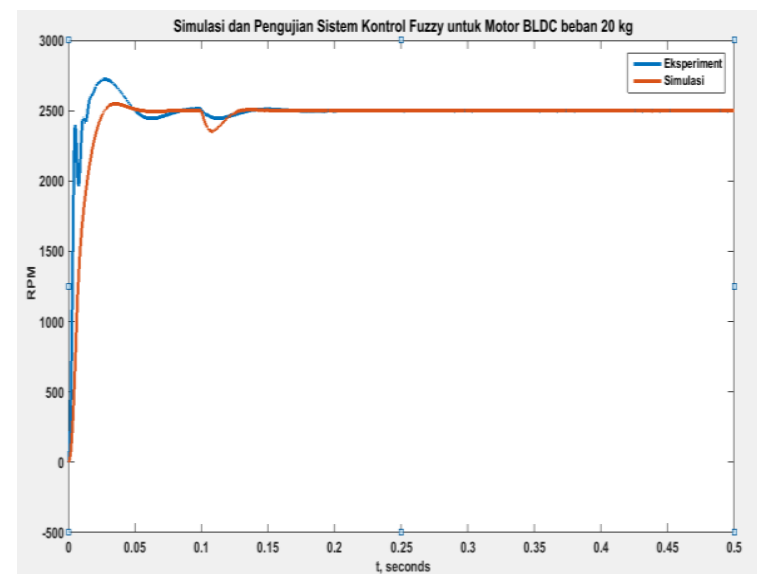

Gambar 6. Simulasi VS Prototype Beban 20kg

Gambar 7 menunjukkan bahwa respon kecepatan naik dari eksperimen sudah hampir mendekati kecepatan naik dari simulasi sebagai referensinya. Pada grafik pembebanan melalui uji alat ini menunjukkan bahwa overshot kecepatan di $3304 \mathrm{rpm}$ saat 0.039 detik dan pada simulasi overshoot kecepatan terjadi pada $3076 \mathrm{rpm}$ saat 0.034 detik, hingga mencapai kecepatan stabil masing - masing pada kecepatan $3000 \mathrm{rpm}$ dan $3043 \mathrm{rpm}$ dengan waktu 0.13 detik dan 0.139 detik pada simulasi dan eksperimen. Terjadi osilasi pada grafik eksperimen tetapi osilasi menghilang setelah 0.15 detik, osilasi terjadi dikarenakan pembebanan yang tiba - tiba pada sensor beban.

Pada pembebanan $40 \mathrm{~kg}$, waktu naik atau respon time pada eksperimen telah mendekati simulasi atau referensinya di 0.027 detik, walaupun overshot yang dimiliki oleh eksperimen masih tinggi di $4323 \mathrm{rpm}$ saat 0.054 detik dikarenakan pembebanan. Waktu steady yang didapat oleh eksperimen tidak seperti pada pembebanan - pembebanan sebelumnya, pada grafik pembebanan $40 \mathrm{~kg}$ ini waktu steady yang didapatkan oleh eksperimen adalah sekitar 0.2 detik pada kecepatan $4001 \mathrm{rpm}$ lebih lambat dari sebelumnya yang mendapatkan 0.15 detik, sedangkan pada simulasi mendapatkan waktu steady pada 0.138 detik dengan kecepatan yang sama dengan eksperimen yaitu $4000 \mathrm{rpm}$. Itu dikarenakan oleh overshot yang terlalu tinggi mengakibatkan perlunya waktu tambahan untuk eksperimen mencapai waktu steadynya pada kecepatan sekitar $4000 \mathrm{rpm}$. 

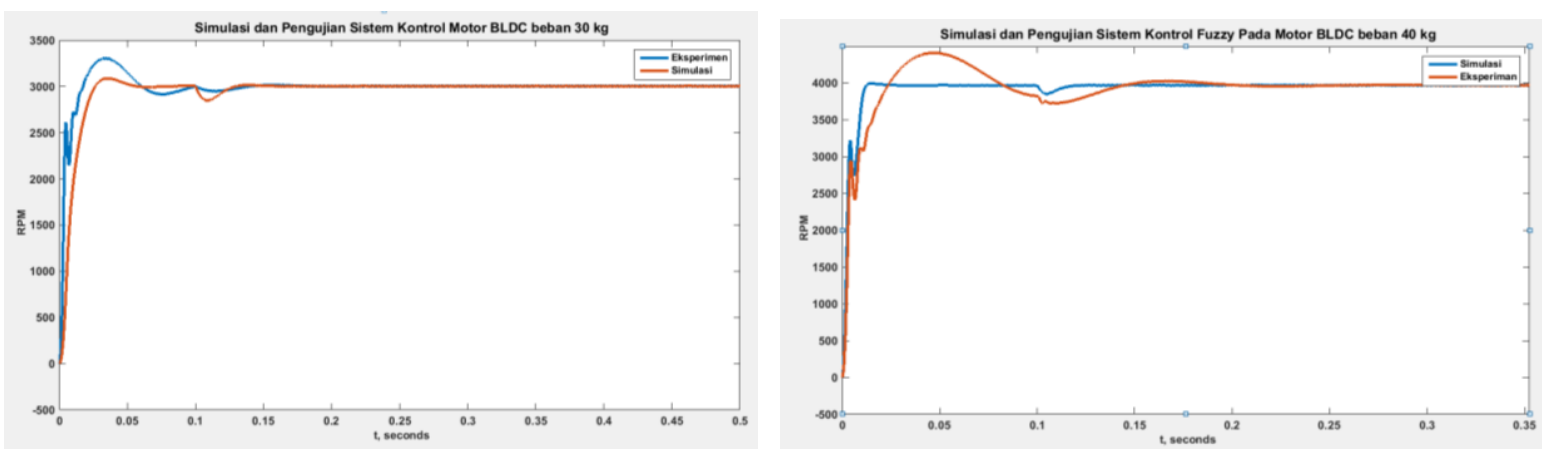

Gambar 7. Simulasi VS Prototype Beban 30kg Gambar 8. Simulasi VS Prototype Beban 40kg

Pada pembebanan 50kg, waktu naikan atau respon dari eksperimen mendekati dari referensinya hanya saja untuk mencapai overshot, waktu yang diperlukan eksperimen lebih dari pembebanan $40 \mathrm{~kg}$ yaitu 0.039 detik. Nilai overshot adalah $5552 \mathrm{rpm}$ saat 0.63 detik, sedangkan pada simulasi mendapatkan 5103 RPM saat 0.035 detik. Untuk mencapai kecepatan stabil eksperimen memerlukan waktu 0.252 detik dengan kecepatan $4494 \mathrm{rpm}$, sedangkan pada simulasi di 0.139 detik dengan kecepatan 5003 RPM.

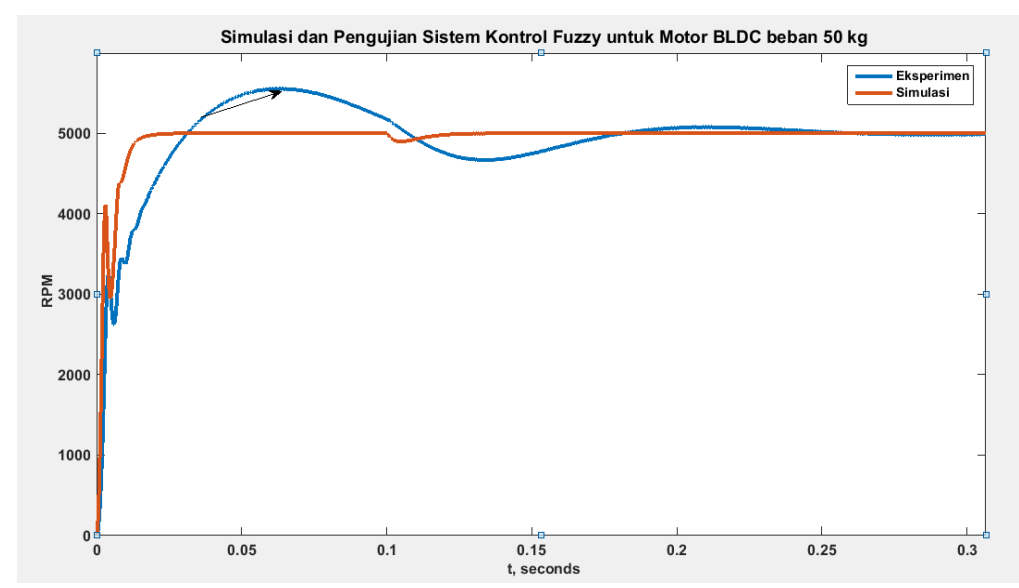

Gambar 9. Simulasi VS Prototype Pada Beban 50kg

Berdasarkan data penelitian dalam bentuk perbandingan komparatif yang telah diperoleh, maka kecerdasan dasar dari grafik tersebut dapat diubah untuk membandingkan hasil perbandingan untuk mendapatkan persentase kesalahan dalam overshot dan kesalahan pada kecepatan antara simulasi sebagai referensi dan prototipe atau percobaan sebagai hasil data perbandingan.

Berdasarkan hasil yang telah dirumuskan pada tabel 1, maka berdasarkan data ini dapat mengetahui nilai overshot dan error hasil kontrol kecepatan motor BLDC antara simulasi dan prototipe. Berikut ini adalah hasil perhitungan berdasarkan tabel data 1: 
Tabel 1.Data Hasil Perhitungan Kontrol Kecepatan

\begin{tabular}{|c|c|c|}
\hline Beban (kg) & Data & Eksperimen \\
\hline \multirow{3}{*}{10} & Overshot $\left(M_{p}\right)$ & 0.085053 \\
\hline & Error $M_{p}$ & 6.468881092 \\
\hline & Error $\omega_{g} \%$ & 0.1687052 \\
\hline \multirow{3}{*}{20} & Overshot $\left(M_{p}\right)$ & 0.094817 \\
\hline & Error $M_{p}$ & 1.757416353 \\
\hline & Error $\omega_{g} \%$ & 0.4798081 \\
\hline \multirow{3}{*}{30} & Overshot $\left(M_{p}\right)$ & 0.085771 \\
\hline & Error $M_{p}$ & 2.385682412 \\
\hline & Error $\omega_{g} \%$ & 1.4333333 \\
\hline \multirow{3}{*}{40} & Overshot $\left(M_{p}\right)$ & 0.0 .08048 \\
\hline & Error $M_{p}$ & 9.384500649 \\
\hline & Error $\omega_{g} \%$ & 0.025 \\
\hline \multirow{3}{*}{50} & Overshot $\left(M_{p}\right)$ & 0.111734 \\
\hline & Error $M_{p}$ & 4.590056067 \\
\hline & Error $\omega_{g} \%$ & 0.1798921 \\
\hline
\end{tabular}

Berdasarkan hasil tabel 1, ini menunjukkan bahwa kesalahan kecepatan yang dihasilkan oleh simulasi dan prototipe tidak terlalu besar, hanya rasio kesalahan pada overshot yang sangat besar. Karena overshot dimiliki oleh prototipe yang cukup besar yang berasal dari input input atau pemuatan tiba-tiba atau tiba-tiba, perbandingan overshot yang diperoleh. Meskipun perbandingan melampaui asimulasi dan prototipe sangat besar, kecepatan yang diperoleh oleh prototipe tidak jauh berbeda dari yang diperoleh oleh simulasi. Baik simulasi dan prototipe mencapai kecepatan stabil atau stabil kurang dari 10 detik. Waktu makan ratarata yang diperoleh antara input beban 10 - $50 \mathrm{~kg}$ menghasilkan waktu mantap kurang dari 0,25 detik.

\section{SIMPULAN}

Kesimpulan yang didapat dari hasil sistem control kecepatan motor BLDC yang membandingkan antara simulasi dan eksperimen ini yaitu :

1. Pada pembebanan $10 \mathrm{~kg}$ sampai $50 \mathrm{~kg}$, kecepatan stabil yang didapat pada perbandingan simulasi dan eksperimen memiliki tingkat error kecepatan sudut yang kecil pada masing - masing pembebanan yaitu $0.16 \%$ pada pembebanan $10 \mathrm{~kg}, 0.47 \%$ pada pembebanan $20 \mathrm{~kg}, 1.43 \%$ pada pembebanan $30 \mathrm{~kg}, 0.025 \%$ pada pembebanan $40 \mathrm{~kg}$ dan $0.179 \%$ pada pembebanan $50 \mathrm{~kg}$.

2. Untuk nilai error overshot pada penelitian ini tidak mendapatkan hasil yang memuaskan dikarenakan nilai overshot pada eksperimen memberikan nilai overshot yang cukup tinggi pada setiap pembebanan. Pada pembebanan $10 \mathrm{~kg}$ mendapatkan 
nilai error 0.096, pada pembebanan $20 \mathrm{~kg}$ mendapatkan 0.129 , pada pembebanan 30 $\mathrm{kg}$ mendapatkan 0.111 , pada pembebanan $40 \mathrm{~kg} 0.088$ sedangkan pada pembebanan $50 \mathrm{~kg}$ mendapatkan nilai 0.131 .

3. Meskipun pada eksperimen mendapatkan nilai overshot yang cukup tinggi dikarenakan pembebanan yang tiba - tiba, akan tetapi waktu steady yang diperlukan masing - masing pembebanan pada eksperimen yaitu dengan rata - rata 0.135 detik pada eksperimen dan dengan waktu yang berbeda pada eksperimen yaitu 0.139 detik pada $10 \mathrm{~kg}, 0.139$ detik pada $20 \mathrm{~kg}, 0.139$ detik pada $30 \mathrm{~kg}, 0.2$ detik pada $40 \mathrm{~kg}$ dan 0.252 detik pada $50 \mathrm{~kg}$.

\section{DAFTAR PUSTAKA}

[1] Bambang Sujanarko, BLDC Motor Control for Electric Vehicle Based On Digital Circuit and Proportional-Integral Controller, International Journal of Advanced Research in lectrical, Electronics and Instrumentation Engineering (An ISO 3297: 2007 Certified Organization) Vol. 3, Issue 9, September 2014

[2] Wenzhuo Li; Jiancheng Fang; Haitao Li; Jiqiang Tang, "Position Sensorless Control Without Phase Shifter for High-Speed BLDC Motors With Low Inductance and Nonideal Back EMF," IEEE Transactions on Power Electronics, vol. 31, no. 2, pp. 1354-1366, Feb. 2016, doi: 10.1109/TPEL.2015.2413593

[3] J. Sriram and K. Sureshkumar, "Speed control of BLDC motor using fuzzy logic controller based on sensorless technique," in 2014 International Conference on Green Computing Communication and Electrical Engineering (ICGCCEE), Coimbatore, India, Mar. 2014, pp. 1-6, doi: 10.1109/ICGCCEE.2014.6922466.

[4] C. Gencer and M. Gedikptnar, Modeling and Simulation of BLDCM Using MATLAB/SIMULINK, Journal of Applied Sciences 6 (3), 2006, pp.688 - 691

[5] K. Neethu, M. Boopathi, Giriraj Mannayee and T.C. Kanish, Fuzzy Logic based Speed Control of BLDC Motor on Sensorless Technique for Space Application, Indian Journal of Science and Technology, Vol. 9 (27), July 2016

[6] Jahir Abbas Mullick, Fuzzy Controller for Speed Control of BLDC motor using MATLAB, International Research Journal of Engineering and Technology (IRJET), Vol. 04 Issue: 02, February 2017 